\title{
Pembuatan Septic Tank Komunal di Desa Leppe Kec.Soropia Kab.Konawe Sulawesi Tenggara
}

\section{Jumartin Gerung*, Andi Mauliyana}

Prodi Kesmas Universitas Mandala Waluya

\begin{abstract}
ABSTRAK
Permasalahan limbah yang kian memburuk di kawasan pesisir khususnya permukiman nelayan tidak dapat tertangani secara baik. Masalah pemukiman pada pembuangan tinja merupakan salah satu masalah kesehatan yang menjadi prioritas. Dengan kondisi rumah warga Desa Leppe Kecamatan Soropia Kabupaten Konawe Provinsi Sulawesi Tenggara yang dibangun di atas permukaan laut, yang menjadi masalah utama adalah tempat pembuangan limbah rumah tangga dan tempat Buang Air Besar (BAB). Kurangnya kesadaran masyarakat untuk membuang air besar di tempat yang layak dengan alasan tidak adanya tempat, harus difasilitasi dengan pembuatan septic tank komunal. Wilayah Desa Leppe dipilih sebagai lokasi program dengan pertimbangan lokasi memadai untuk program sanitasi dan sebagian warganya menerapkan sanitasi yang sederhana. Tujuan program ini adalah meningkatkan akses sanitasi dan pemahaman warga untuk menggunakan dan memelihara sarana sanitasi (septic tank komunal dan sambungan rumah) yang dibangun, membangun sarana sanitasi untuk warga, mengurangi BAB sembarangan dan penerapan PHBS (Pola Hidup Bersi dan Sehat) serta meningkatkan derajat kesehatan lingkungan di wilayah tersebut. Metode yang dilakukan untuk menentukan prioritas masalah dalam pengabdian ini yakni dengan menggunakan Metode CARL (Capability, accessibility, Readiness, Leverage), yang merupakan suatu teknik atau cara yang digunakan untuk menentukan prioritas suatu masalah apabila data yang tersedia adalah data kualitatif. Metode ini dilakukan dengan menentukan skor atas kriteria tertentu. Dari pengabdian masyarakat yang dilakukan, telah berhasil dibangun septic tank komunal yang dapat dimanfaatkan dua hingga tiga rumah warga. Daerahnya yang berbeda dengan daratan membuat pembangunan septic tank komunal ini disesuaikan dengan lingkungan warga dan memastikan tinja tidak lagi mengotori lingkungan warga.
\end{abstract}

Kata kunci: Septic tank komunal; Sanitasi; Sulawesi Tenggara.

\section{Construction of Communal Septic Tanks in Leppe Village, Soropia District, Konawe Regency, Southeast Sulawesi}

\begin{abstract}
The problem in coastal settlement areas, especially fishermen settlements, cannot be handled properly. The problem of environmental sanitation, especially in the disposal of feces, is one of the various health problems that need to be prioritized. With the condition Leppe Village residents which are built above sea level, it is natural that the main problems in this area are the place for disposal of household waste and places for defecating (BAB). Lack of public awareness to defecate in an appropriate place on the grounds of not having a place, must be facilitated by the construction of a communal septic tank. The area of Leppe Village was chosen as the location of the program with consideration of an adequate location for the sanitation program and some of the residents applied simple sanitation. The aim of this program was to improve sanitation access and people's understanding of how to use and maintain sanitation facilities (communal septic tanks and house connections), to build sanitation facilities for residents, to reduce open defecation and the application of PHBS and improve environmental health in the area. The method used to determine the priority of problems in this service was the CARL method which is a technique used to determine the priority of a problem if the available data is qualitative data. This method is done by determining a score on certain criteria. From this community service activity, a communal septic tank was successfully built that can be used by two to three residents' houses. The area which is different from the mainland has made the construction of this communal septic tank adapted to the community's environment and ensures that the feces will no longer pollute the residents' environment.
\end{abstract}

Keywords: Communal septic tank; Sanitation; Southeast Sulawesi.

\section{Penulis Korespondensi :}

Jumartin Gerung

Prodi Kesmas Universitas Mandala Waluya

E-mail : jumartin.gerung@gmail.com

No. Hp : 085255852718 


\section{PENDAHULUAN}

Kesehatan adalah keadaan fisik, mental dan sosial, bukan hanya tidak adanya penyakit atau kelemahan. Semua orang di beberapa titik bersedia untuk membayar apa pun untuk menjaganya.

Sumberdaya pantai dan laut dikenal sebagai sumberdaya multi fungsi. Wilayah perairan pantai yang kaya akan sumberdaya alam telah dimanfaatkan oleh bangsa Indonesia sebagai salah satu sumber bahan makanan, utamanya protein, sejak berabad-abad lamanya. Selain itu, pemanfaatan sumber energi, seperti hidrokarbon dan mineral khususnya di wilayah pesisir dan laut, telah dilakukan untuk menunjang pembangaunan pada sektor ekonomi (Gerung \& Wulandari, 2020).

Fungsi lain yang dimiliki oleh wilayah pesisir dan lautan digunakan untuk berbagai kegiatan seperti transportasi, pelabuhan, industri, agrobisnis dan agroindustri, rekreasi dan pariwisata, kawasan pemukiman, dan tempat pembuangan limbah.

Wilayah pesisir dan lautan merupakan prioritas utama bagi pusat kegiatan pengembangan industri, pariwisata, agribisnis, agroindustri, pemukiman, transportasi, dan pelabuhan. Di balik prospek di atas, pengalaman pembanguan sumberdaya pesisir dan lautan umumnya mengarah ke suatu pola yang merusak daya dukung lingkungan dan tidak berkesinambungan (unsustainable) (Resty, 2018).

Sistem multifungsi yang tidak terencana dengan baik telah menunjukkan kemunduran mutu lingkungan wilayah pesisir dan lautan, konflik kepentingan antara kegiatan maupun sektor, pencemaran dan over eksploitasi sumberdaya.

Tidak adanya integrasi dan koordinasi perencanaan masing-masing sektor mengakibatkan tidak tercapainya tujuan pembangunan secara optimal dan terganggunya fungsi utama di perairan tersebut.

Menyadari adanya karakteristik dan dinamika alamiah ekosistem pesisir dan lautan yang secara ekologis saling terkait satu dengan lainnya, demikian pula dengan ekosistem lahan atas, serta keanekaragaman sumberdaya alam dan jasa-jasa lingkungan sebagai potensi pembangunan, mensyaratkan pembangunan sumberdaya pesisir dan lautan yang optimal dan berkelanjutan.

Permasalahan air limbah yang kian memburuk di kawasan permukiman pesisir khususnya permukiman nelayan tidak dapat tertangani secara baik. Latar belakang penyebabnya adalah: (1) kebiasaan sosial-budaya yang sulit berubah, (2) topografi yang sangat rendah bahkan sebagian berada dibawah ketinggian pasang air laut (karena abrasi) (3) perkembangan permukiman yang kian memadat dan tidak tertata dan (4) kegagalan penerapan standar teknis pembuangan air limbah. (Resty, 2018)

Masalah kesehatan lingkungan pemukiman khususnya pada pembuangan tinja merupakan salah satu dari berbagai masalah kesehatan yang perlu mendapatkan prioritas. Penyediaan sarana pembuangan tinja masyarakat terutama dalam pelaksanaannya tidaklah mudah, karena menyangkut peran serta masyarakat 
yang biasanya sangat erat kaitannya dengan prilaku, tingkat ekonomi, kebudayaan dan pendidikan (Notoatmodjo, 2007).

Pembuangan tinja perlu mendapat perhatian khusus karena merupakan satu bahan buangan yang banyak mendatangkan masalah dalam bidang kesehatan dan sebagai media bibit penyakit, seperti diare, typhus, muntaber, disentri, cacingan dan gatalgatal. Selain itu dapat menimbulkan pencemaran lingkungan pada sumber air dan bau busuk serta estetika (Soedjono \& Fitriani, 2016).

Berdasarkan hasil observasi yang dilakukan dan berdasarkan data primer didapatkan bahwa dari keempat faktor yang mempengaruhi status kesehatan masyarakat, yang paling berpengaruh adalah faktor perilaku (kesadaran masyarakat berperilaku hidup sehat untuk mencapai derajat kesehatan yang optimal yang telah dicanangkan oleh pemerintah) (Sumantri, 2017).

1. Lingkungan

Berdasarkan hasil survei terlihat bahwa keadaan lingkungan di Desa Leppe Kecamatan Soropia, Kabupaten Konawe, Provinsi Sulawesi Tenggara, masih kurang baik, hal ini di akibatkan karena banyaknya sampah yang berserakan di pinggir laut yang berada disekitar pemukiman warga. Selain itu juga masih banyak masyarakat yang membuang air besar langsung ke laut yang dapat mengakibatkan pencemaran terhadap lingkungan sekitar khusnya air laut tersebut.

Dari hasil wawancara dengan masyarakat, keadaan lingkungan sekitar yang masih kurang baik dikarenakan tidak adanya tempat atau lahan yang bisa di gunakan untuk membuat tempat penampungan kotoran, karena daerah atau tempat tinggal mereka yang berada di atas air laut. Selain itu kurangnya fasilitas penunjang kesehatan seperti Jamban umum dan tempat sampah. sehingga masyarakat masih masih kurang menyadari akan pentingnya kesehatan lingkungan.

\section{Perilaku}

Perilaku adalah respon individu terhadap suatu stimulus atau suatu tindakan yang dapat diamati dan mempunyai frekuensi spesifik, durasi dan tujuan baik disadari maupun tidak.

Untuk mengetahui status kesehatan seseorang, pertama adalah merubah perilaku orang tersebut seperti di Desa Leppe dimana banyak perilaku penduduk, baik disadari maupun tidak mempengaruhi status kesehatan mereka.

Saat melakukan survei lokasi, ditemukan adanya perilaku yang tidak sesuai dengan prinsip hidup sehat, seperti adanya kebiasaan dari sebagian besar masyarakat desa masih Buang Air Besar (BAB) langsung ke laut.

Selain itu kebiasaan membuang sampah ke laut dan di sekitar rumah dapat mencemari air laut dan membahayakan bagi kehidupan biota laut. Perilaku negatif tersebut diakibatkan karena tidak adanya fasilitas penunjang kesehatan seperti tidak adanya Jamban umum yang sehat dan Tempat Sampah.

Penduduk Desa Leppe sebagian besar adalah penduduk suku Bajo. Bentuk rumah penduduk di Desa Leppe sebagian besar adalah rumah panggung yang kebanyakan adalah bangunan 
lama, tapi ada juga rumah permanen dan semi permanen.

Kebanyakan penduduk pada daerah Desa Leppe berprofesi sebagai Nelayan, sehingga pendapatan mereka tidak menentu perharinya tergantung dari hasil penjualan ikan yang mereka tangkap. Hal ini turut mempengaruhi upaya masyarakat khususnya dalam hal pengadaan jamban dan septic tank komunal.

Sebagai daerah Pesisir, kedua Desa tersebut memiliki permasalahan mendasar dalam hal saluran pembuangan tinja manusia. Sebagaimana diketahui ada beberapa faktor yang harus diperhatikan dalam pembuatan jamban khususnya di daerah pesisir.

dengan daratan pada umumnya
membutuhkan tempat yang lebih kondusif agar kotoran manusia justru tidak mencemari lingkungan sekitar. Dalam pembuatan jamban sendiri patut memperhatikan (Marlinae et al., 2019):

1. Kondisi daerah, datar atau miring

2. Tinggi rendahnya permukaan air

3. Arah aliran air tanah

4. Sifat, macam dan struktur tanah Program pembangunan septic tank komunal di Desa Leppe sendiri merupakan bagian dari kegiatan pengabdian kepada masyarakat yang diinisiasi pihak kampus yang membutuhkan kerjasama dengan warga. Program ini dimaksudkan untuk mendorong warga untuk berpola hidup bersih dan sehat.

Wilayah Desa Leppe dipilih sebagai lokasi program dengan pertimbangan lokasi memadai untuk program sanitasi dan sebagian warganya menerapkan sanitasi yang sederhana. Tujuan program ini adalah meningkatkan akses sanitasi dan pemahaman warga untuk menggunakan dan memelihara sarana sanitasi (septic tank komunal dan sambungan rumah) yang dibangun, membangun sarana sanitasi untuk warga, mengurangi BAB sembarangan dan penerapan PHBS serta meningkatkan derajat kesehatan lingkungan di wilayah tersebut.

Berdasarkan latar belakang yang telah dikemukakan diatas, maka masalah yang akan dikaji dalam Program Pengabdian Pada Masyarakat ini adalah bagaimana mengoptimalkan peran masyarakat melalui upaya pelatihan dan pembuatan septic tank komunal dalam peningkatan kesehatan masyarakat khususnya kesehatan lingkungan di wilayah pesisir.

\section{METODE}

\section{Pengambilan Data}

Data Primer dilakukan melalui wawancara kepada responden dengan menggunakan kuesioner serta observasi langsung. Sedangkan data sekunder diperoleh dengan cara mengambil data di puskesmas dan pemerintah Desa setempat. Berdasarkan data yang diperoleh menunjukkan bahwa populasi masyarakat Desa Leppe berjumlah 166 KK dan 489 Jiwa.

\section{Identifikasi Masalah}


Berdasarkan Observasi dan wawancara yang dilakukan, terdapat tiga prioritas masalah yang ditemukan yakni :

1. Tempat Pembuangan Akhir (TPA)

2. Pembuatan Septic tank komunal

3. Saluran Pembuangan Air Limbah

Setelah masalah dan alternatif pemecahan masalah diidentifikasi, maka dilakukan pemberian skor untuk menetapkan masalah mana yang paling urgen untuk diatasi dengan metode CARL.

Metode $\boldsymbol{C A R L}$ merupakan suatu teknik atau cara yang digunakan untuk menentukan prioritas suatu masalah apabila data yang tersedia adalah data kualitatif. Metode ini dilakukan dengan menentukan skor atas kriteria tertentu. Semakin besar skor yang diperoleh, maka semakin besar pula suatu masalah yang dihadapi, sehingga menjadi semakin tinggi letaknya pada urutan prioritasnya.

Metode $\boldsymbol{C A R L}$ merupakan metode yang cukup baru di bidang kesehatan. Metode CARL juga didasarkan pada serangkaian kriteria yang diberi skor. Kriteria dalam metode $C A R L$ tersebut mempunyai arti:
C = Capability yaitu ketersediaan sumber daya (dana, sarana dan peralatan)

$\mathrm{A}=$ Accessibility yaitu kemudahan, masalah yang ada mudah diatasi atau tidak. Kemudahaan dapat didasarkan pada ketersediaan metode / cara / teknologi serta penunjang pelaksanaan seperti peraturan atau juklak.

$\mathrm{R}=$ Readiness yaitu kesiapan dari tenaga pelaksana maupun kesiapan sasaran, seperti keahlian atau kemampuan dan motivasi.

$\mathrm{L}$ = Leverage yaitu seberapa besar pengaruh kriteria yang satu dengan yang lain dalam pemecahan masalah yang dibahas.

Skoring dari tiga masalah yang ada didasarkan pada ketentuan pemberian nilai sebagai berikut :

Nilai 5 : Paling bermasalah (mutlak)

Nilai 4 : Sangat menjadi masalah

Nilai 3 : Cukup menjadi masalah

Nilai 2 : Tidak menjadi masalah

Nilai 1 : Sangat tidak menjadi masalah

Skor dihitung sesuai nilai total yang merupakan hasil dari perkalian CxAxRxL. Hasil penghitungan dari prioritas masalah dapat ditunjukkan pada tabel berikut :

\begin{tabular}{|c|c|c|c|c|c|c|}
\hline Masalah & C & A & R & L & NILAI & RANK \\
\hline TPA & 3 & 4 & 4 & 4 & 192 & 3 \\
\hline $\begin{array}{c}\text { Septic } \\
\text { tank }\end{array}$ & 5 & 4 & 4 & 5 & 400 & 1 \\
\hline SPAL & 5 & 4 & 4 & 4 & 320 & 2 \\
\hline
\end{tabular}


Dari tabel di atas terlihat bahwa prioritas masalah yang ditetapkan adalah intervensi pembuatan septic tank komunal yang diperuntukkan bagi 2-3 rumah warga.

Septic tank dibuat dengan mengikuti langkah-langkah berikut ini:

- Tanah digali sebagai wadah septic tank sedalam 1,5 meter dengan tinggi 2 meter.

- Membuat sekat pada tengah galian untuk membuat 2 kolom septic tank yang berdempetan yang bertujuan untuk memisahkan kotoran padat dan cair.

- Membuat penghubung antar sekat dengan menggunakan paralon berukuran 4 inch.

\section{HASIL DAN PEMBAHASAN}

\section{Pembuatan Septic Tank Komunal}

Secara umum, kondisi lingkungan Desa Leppe masih terlihat semrawut. Hal ini di akibatkan karena banyaknya sampah yang berserakan di pinggir laut yang berada di sekitar pemukiman warga. Selain itu juga masih banyak masyarakat yang membuang air besar langsung ke laut yang dapat
- Paralon dari arah masingmasing WC warga dibuat menurun sejajar sampai arah pembuangan.

- Membuat bahan material dinding septic tank menggunakan bata merah yang diplester.

- Membuat tembok alas pada septic tank untuk mencegah roboh atau bocor

Septic tank komunal dibangun setelah berdiskusi dengan warga mengenai lokasi pembangunan, dibuatlah satu unit septic tank komunal untuk tiga rumah di dusun 3 Desa Leppe, Kec. Soropia, Kabupaten Konawe.

mengakibatkan pencemaran terhadap lingkungan sekitar khusnya air laut tersebut.

Berdasarkan observasi yang dilakukan terhadap masyarakat, keadaan lingkungan sekitar yang masih kurang baik dikarenakan tidak adanya tempat atau lahan yang bisa di gunakan untuk membuat tempat penampungan kotoran, karena daerah atau tempat tinggal mereka yang berada di atas air laut. 


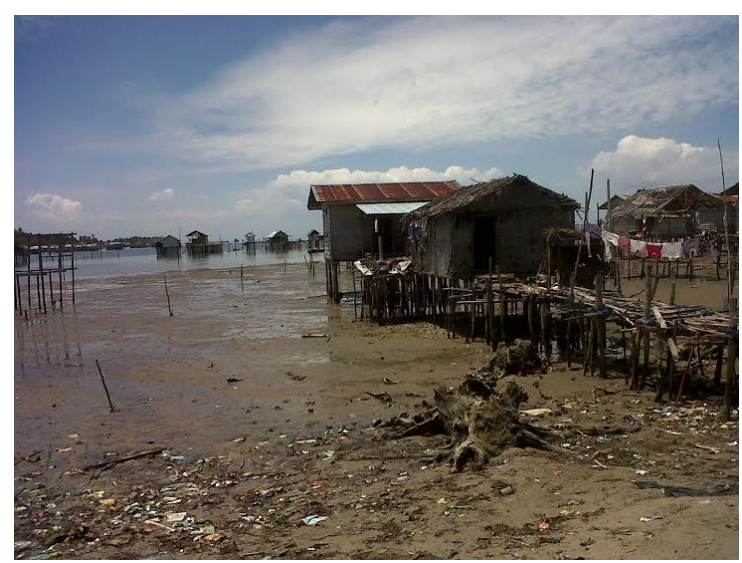

Gambar 1. Kondisi Rumah Warga di Desa Leppe

Dengan kondisi rumah warga yang dibangun di atas permukaan laut, yang menjadi masalah utama adalah tempat pembuangan limbah rumah tangga dan tempat Buang Air Besar
(BAB). Kurangnya kesadaran masyarakat untuk membuang air besar di tempat yang layak dengan alasan tidak adanya tempat, harus difasilitasi dengan pembuatan septic tank komunal.

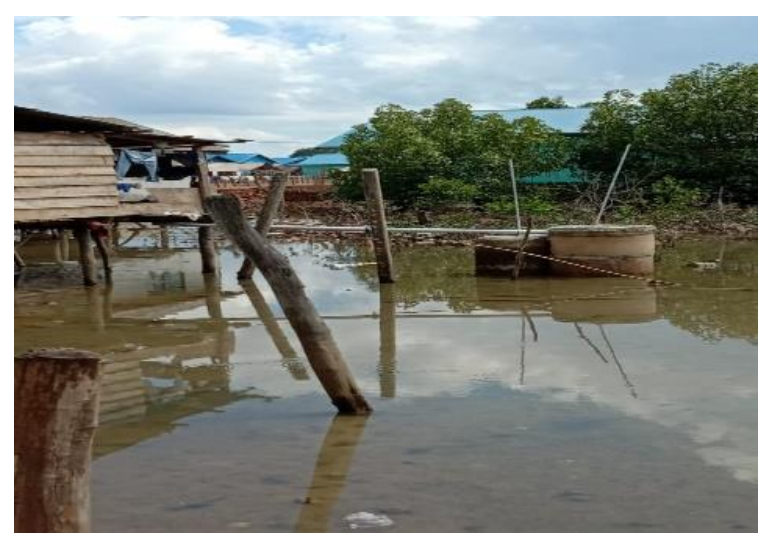

Gambar 2. Pembangunan Septic Tank

Pembuatan Septic tank Komunal dilakukan pada Februari 2020 dilokasi yang telah disepakati warga yakni di Dusun II Desa Leppe Kec. Soropia Kab. Konawe. Jumlah septic tank komunal yang di buat berjumlah 1 unit untuk 2 3 rumah.

Dalam pembuatan Septic tank komunal ini masyarakat setempat turut memberikan sumbangan bahan untuk membuat Septic tank komunal berupa pasir, batu, batako, closet, cincin, balok,kerikil. Serta bantuan tenaga dalam proses pemuatan septic tank komunal ini.

\section{Berdasarkan hasil yang} ditemukan saat survei awal terlihat bahwa masih terdapat beberapa warga yang kurang atau tidak mengetahui apa pentingnya pengadaan dan pengadaan septic tank, penggunaan jamban dengan baik, serta dampak yang akan ditimbulkan akibat tidak tersedianya jamban pada satu rumah tangga. 
Disinilah nampak betapa pentingnya peningkatan terhadap pengetahuan masyarakat agar terjadi pula peningkatan terhadap tindakan sebagai aplikasi terhadap pengetahuan yang dimiliki.

Masyarakat yang tidak memiliki jamban ini lebih memilih untuk buang air besar langsung ke Laut, dan lebih memilih membuang air besar pada jamban yang tidak memenuhi syarat kesehatan seperti jamban cemplung. Alasan utama lainnya yang mereka kemukakan adalah faktor ekonomi yang tidak mencukupi untuk pembuatan jamban di rumah mereka.

Tahapan pembuatan septic tank komunal pertama yang mesti dilakukan adalah menentukan lokasi, menyiapkan bahan, kemudian proses dudukan closet kemudian penggalian septic tank hingga mencapai kedalaman kurang lebih 1meter. Lubang yang telah ada kemudian dimasukan cincin yang sudah disesuaikan dengan besarnya lubang galian.

Setelah itu, dilakukan penutupan lubang menggunakan penutup cincin yang sudah disediakan, kemudian dilakukan proses pemasangan pipa dari kloset ke lubang septic tank. Proses selanjutnya pemasangan kloset. Demikian setelah itu dilakukan proses pengacian lantai kamar mandi. Dan yang terakhir proses pembuatan dinding dan atap kamar mandi.

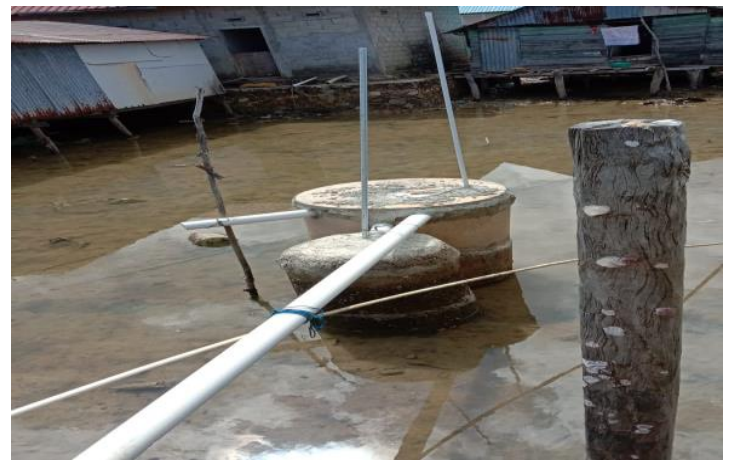

Gambar 4. Septic Tank komunal yang dapat digunakan 2-3 rumah

Sebagai tempat penampungan dan pengolahan tinja sementara, keberadaan septic tank penting untuk mencegah penularan penyakit dan penyebaran bakteri. Selain itu, septic tank juga solusi mencegah timbunan tinja mencemari air dan lingkungan. Pemerintah juga sudah membuat peraturan tentang septic tank. Ketentuannya diatur dalam Peraturan
Menteri Kesehatan (Permenkes) Nomor 3 Tahun 2014 tentan Sanitasi Total Berbasis Masyarakat.

$$
\text { Berdasarkan lampiran dalam }
$$
Permenkes tersebut, setiap jamban perlu dilengkapi dengan fasilitas septic tank. Adapun septic tank adalah suatu bak kedap air yang berfungsi sebagai tempat penampungan limbah kotoran 
manusia (tinja dan urine). Bagian padat kotoran manusia akan tertinggal dalam tangki septik.

Sedangkan bagian cairnya keluar dari tangki septik dan diresapkan melalui bidang atau sumur resapan. Jika tidak memungkinkan dibuat resapan maka dibuat suatu filter untuk mengelola cairan itu. Sedangkan menurut ketentuan Standar Nasional Indonesia (SNI) 2398:2017, septic tank harus kedap air.

Septic tank juga perlu memiliki lubang kontrol, ventilasi, pipa masukkeluar serta harus dikuras isinya, untuk dibuang dengan truk tinja secara reguler. Limbah dari septic tank itu dikirim ke Instalasi Pengoalhan Lumpur Tinja (IPLT). Ketentuan SNI 2398:2017 lainnya mengharuskan septic tank memiliki bagian penampungan dan pengolah air limbah dengan kecepatan aliran lambat. Tujuannya memberia kesempatan pengendapan benda padat agar terjadi penguraian menjadi bahan larut air dan gas.

\section{Penyuluhan Pemanfaaan Septic Tank Komunal}

Selain membuat septic tank komunal, kami juga melakukan penyuluhan pada masyarakat Desa Leppe pada tanggal 19 Februari 2020. Penyuluhan ini di maksudkan untuk menambah pengetahuan masyarakat setempat mengenai pembuatan dan manfaat penggunaan septic Tank Komunal bagi masyarakat di daerah pesisir.
Meski saat ini, di tengah kemajuan pengetahuan dan teknologi yang memungkinkan masyarakat bisa mengakses berbagai macam informasi, namun penyuluhan kesehatan khususnya terkait masalah kesehatan lingkungan masih sangat relevan.

Hadirnya jejaring media sosial memang semakin menjembatani seseorang untuk memiliki banyak keterhubungan, baik secara offline maupun online. Namun tugas melakukan penyuluhan adalah bagian yang tidak dapat dipisahkan dari tenaga kesehatan masyarakat.

Melalui penyuluhan yang di lakukan di harapkan Masyarakat Desa Leppe dapat mengetahui pemanfaatan Septic Tank Komunal sebagai alternatif yang efektif tempat penampungan limbah bagi masyarakat di daerah Pesisir, sehingga dapat meningkatkan derajat kesehatan masyarakat khususnya di bidang kesehatan lingkungan.

\section{KESIMPULAN}

Masalah penyehatan lingkungan pemukiman khususnya pada pembuangan tinja merupakan salah satu dari berbagai masalah kesehatan yang perlu mendapatkan prioritas. Dengan kondisi rumah warga yang dibangun di atas permukaan laut, yang menjadi masalah utama adalah tempat pembuangan limbah rumah tangga dan tempat Buang Air Besar (BAB). Kurangnya kesadaran masyarakat untuk membuang air besar di tempat yang layak dengan alasan tidak adanya tempat, harus difasilitasi dengan pembuatan septic tank komunal. 
Wilayah Desa Leppe dipilih sebagai lokasi program dengan pertimbangan lokasi memadai untuk program sanitasi dan sebagian warganya menerapkan sanitasi yang sederhana melalui pembuatan septic tank komunal untuk mengurangi perilaku BAB di sembarang tempat serta meningkatkan derajat kesehatan lingkungan di suatu wilayah dimana lingkungan merupakan salah satu penentu derajat kesehatan masyarakat.

\section{UCAPAN TERIMA KASIH}

Ucapan terima kasih kami haturkan kepada yayasan Mandala Waluya dan LPPM Universitas Mandala Waluya yang telah memberikan bantuan berupa dana kegiatan pemberdayaan masyarakat, serta masyarakat Desa Leppe dan Mahasiswa Prodi kesehatan masyarakat yang telah membantu terlaksananya pengabdian masyarakat ini.

\section{DAFTAR PUSTAKA}

Gerung, J., \& Wulandari, A. R. (2020). Hubungan Pengetahuan, Sikap, Dan Hygiene Perorangan Penjamah Makanan Pada Penyelenggaraan Makanan Di Kantin Sma Negeri 4 Kendari. MIRACLE JOURNAL OF PUBLIC HEALTH, 3(1), 25-32. https://doi.org/10.36566/MJPH/VOL3.ISS1/1 35

Marlinae, L., Khairiyati, L., Rahman, F., \& Laily, N. (2019). Buku Ajar Dasar-Dasar Kesehatan Lingkungan. Fakultas Kedokteran Universitas Lambung Mangkurat Banjarbaru, 1-120. http://kesmas.ulm.ac.id/id/wpcontent/uploads/2019/02/BUKU-AJARDASAR-DASAR-KESEHATANLINGKUNGAN.pdf

Notoatmodjo, S. (2007). Promosi Kesehatan \& IImu Perilaku.

http://r2kn.litbang.kemkes.go.id:8080/handl e/123456789/77273

Resty, A. U. (2018). Dampak Sanitasi Lingkungan Terhadap Kesehatan Masyarakat Di Wilayah Pesisir Kecamatan Kota Agung. In JPG (Jurnal Penelitian Geografi) (Vol. 6, Issue 7). http://jurnal.fkip.unila.ac.id/index.php/JPG/ article/view/16933

Soedjono, E. S., \& Fitriani, N. (2016). Penyediaan Jamban Sehat Sederhana Untuk Masyarakat Berpenghasilan Rendah Berbasis Pemberdayaan Masyarakat Di Kelurahan Tambakwedi, Kecamatan Kenjeran, Kota Surabaya. Jurnal Sains \&Teknologi Lingkungan, $\quad 8(1), \quad 36-45$. https://doi.org/10.20885/jstl.vol8.iss1.art4

Sumantri, A. (2017). Kesehatan Lingkungan - Edisi Revisi. Prenada Media. 